\title{
Immobilization of inulinase from Aspergillus niger on octadecyl substituted nanoporous silica; Inulin hydrolysis in a continuous mode operation
}

\author{
Mahsan Karimi a , Mehran Habibi-Rezaei a, b,*, Keramatollah Rezaei ${ }^{\text {c, }}$ Ali Akbar Moosavi-Movahedi ${ }^{\mathrm{d}}$, \\ Jozef Kokini e
}

\footnotetext{
a School of Biology, College of Science, University of Tehran, Tehran, Iran

b Nanobiomedicine Center of Excellence, Nanoscience and Nanotechnology Research Center, University of Tehran, Tehran, Iran

c Department of Food Science and Engineering, Faculty of Agricultural Engineering and Technology, University of Tehran, Karaj, Iran

${ }^{\mathrm{d}}$ Institute of Biochemistry and Biophysics, University of Tehran, Tehran, Iran

e Department of Food Science, College of Agriculture, University of Purdue, Lafayette, Indiana, USA
}

*Corresponding author: Tel.: +98-21-61113214; mhabibi@ut.ac.ir.

\author{
E-mail addresses: \\ karimimahsun@gmail.com (M. Karimi) \\ mhabibi@ut.ac.ir (M. Habibi-Rezaei) \\ krezaee@ut.ac.ir (K. Rezaee) \\ moosavi@ut.ac.ir (A. A. Moosavi-Movahedi) \\ jkokini@purdue.edu (J. Kokini)
}




\begin{abstract}
Inulinase hydrolyzes inulin and produce high fructose syrup in a single-step reaction. However, finding the best working conditions and the highest inulinase stability, especially in continuous mode operations are of critical value. Native (endo-inulinase (EC 3.2.1.7)) and chemically modified inulinases (endo-inulinase stabilized with pyridoxal 5'-phosphate /ascorbic acid in a semi-rational chemical modification approach) were immobilized on octadecyl substituted nanoporous silica (with the average pore size of $66 \mathrm{~nm}$ ) by using dioxane to extend the hydrophobic interactions between inulinase refolding intermediates and the hydrophobic alkyl moieties of the support. Native and modified inulinases revealed their maximum surface hydrophobicity at 40 and $50 \%$ dioxane in water, respectively. Immobilized inulinases (native and modified) showed 7.89 and 3.73 fold increase in their half lives compared to the free native sample., higher reusability compared to free inulinases (native and modified) and also could retain their activities after 10 hydrolysis cycles in a continuous mode of experimental conditions.
\end{abstract}

Key words: inulinase, immobilization, nano-porous silica 


\section{Introduction}

Inulin is a storage polyfructan found in the underground parts of Compositae and Gramineae families containing linear $(2 \rightarrow 1)$ linkages between fructose residues and a sucrose moiety at the end of its chain (Ronkarta et al., 2007). Due to its low solubility in water at room temperature and its susceptibility to microbial contamination, industrial hydrolysis of inulin should be performed at higher temperatures. (Gill et al., 2006). There are two different subclasses of inulinase: exo-inulinase (EC 3.2.1.80) which hydrolyses the terminal bonds of inulin chain to produce fructose and endo-inulinase (EC 3.2.1.7) which cleaves the internal bonds of inulin to produce fructose and fructooligosaccharide (Cruz et al., 1998; Barthomeuf et al., 1991; Nakamura et al., 1995; Pandey et al., 1995; Krieger \& Fontana, 1999). Tertiary structure of inulinase consists of $\mathrm{N}$-terminal catalytic domain with a 5-bladed $\beta$-propeller fold and C-terminal domain which folds into a sandwich-like structure. A short polypeptide linker connects these two parts (Nagem et al., 2004; Kim et al., 2005).

Free enzymes have restricted applications in industry because they have restricted operational and storage stability, their recovery or reusability is not possible, they could be irreversibly inactivated through aggregation (Risso et al., 2010; Knubovets et al., 2009) and since there is always a risk of allergic reactions due to final product contamination with proteins, (Vasileva \& Godjevargova, 2005). Inulinase hydrolyzes inulin in a single-step reaction and produces high fructose syrup (HFS) which has a wide range of applications in food and pharmaceutical industries. Fructose is a GRAS sweetener, which is sweeter and than sucrose, and has functional properties which could enhance product flavor, color and stability, thus could be easily used instead of sucrose (Rocha et al., 2006). There is a growing interest in producing inulinases with improved thermal stability to ensure appropriate hydrolysis rate and also to 
inhibit microbial growth in inulin, so in this research, inulinase modified with pyridoxal 5'phosphate/ascorbic acid in a semi-rational chemical approach was used which has $8.1^{\circ} \mathrm{C}$ higher melting temperature and improved thermal stability compared to native inulinase (Torabizadeh et al., 2010). Since high yield processes are preferred in industry, inulinase immobilization seems helpful in multi-usage of the enzyme, and in overcoming the protein-protein interactions and aggregations (Risso et al., 2010; Knubovets et al., 2009). Enzyme immobilization offers higher stability, reusability and makes the continuous application of the enzyme, possible. Enzymes has been immobilized through a wide variety of the strategies (Ettalibi \& Baratti, 2001; Rocha et al., 2006; Barranco-Florido et al. 2001; Uzunova et al., 2002) like adsorptive binding which mainly suffers from leakage, but at the same time is the easiest and the least denturing method (Sassolas et al., 2012). Covalent binding, cross linking using glutaraldehyde (Karimi et al, 2014 a) and electrostatic attachment (Karimi et al, 2014 b) of the inulinase to the carrier have been reported. Using silica nanoparticles as support to immobilize enzymes offers some advantages owing to its high surface area, large pore volume, uniform and tunable pore sizes, outstanding physicochemical constancy, well-regulated shape, adaptable surfaces, nontoxic nature and well biocompatibility (Tourné-Péteilh et al., 2003). Presence of dioxane makes octadecyl groups of silica support, exposed and at the same time inulinase refolding intermediates with extended hydrophobic surfaces forms that could easily adhere to each other through adsorptive forces.However, in this work we reported a novel adsorptive immobilization strategy that was used for the first time to immobilize both native and PLP/Ascorbate modified inulinases, then applying themin a continuous bioconversion of inulin in a fluidized bed mini-bioreactor. 


\section{Materials and Methods}

\subsection{Chemicals}

Nano porous silica, Trichloro (octadecyl) silane (OTS) and dioxane were purchased from Merck (Darmstadt, FRG). 8-Anilino-1-naphthalen sulfonic acid (ANS), sodium potassium tartrate and 3, 5-Dinitrosalicylic acid (DNS) were prepared from Sigma Chemical Company (St. Louis, MO, USA). Inulin (Chicory), pyridoxal 5'-phosphate (PLP) and inulinase (EC 3.2.1.7) from Aspergillus niger were obtained from Fluka (Switzerland). Ascorbic acid was from Acros Organics (New Jersey, USA). All other chemicals were of analytical grade. Acetate sodium buffer $(50 \mathrm{mM}), \mathrm{pH} 5.5$ was prepared in $0-60 \%(\mathrm{v} / \mathrm{v})$ ratios of dioxane to water. All the experiments were repeated three times and the results are the mean value of three experiments.

\subsection{Protein assay}

Protein content was estimated using the Bradford method (Bradford, 19761) and the bound protein was calculated by subtracting the total loaded protein from the protein recovered in the supernatant and washing solutions (Nabati et al., 2011).

\subsection{Inulinase activity assay}

Concentration of the liberated sugar after the hydrolysis action by free and immobilized enzymes, was estimated with DNS (3, 5-Dinitrosalicylic acid) method. To prepare solution of $1 \%$ DNS; $10 \mathrm{~g}$ DNS, $1 \mathrm{~g}$ phenol, $0.5 \mathrm{~g} \mathrm{Na}_{2} \mathrm{SO}_{3}, 10 \mathrm{~g} \mathrm{NaOH}$ and $1 \mathrm{~L}$ of distilled water were mixed and gently stirred until a clear solution. was developed. Reaction mixture contained 400 $\mu \mathrm{L}$ of inulin $0.2 \%$ and $100 \mu \mathrm{L}$ of inulinase (native or modified) in sodium acetate buffer (pH 5.5, $50 \mathrm{mM}$ ). The reaction mixture was incubated at $45^{\circ} \mathrm{C}$ for 30 minutes (Nakamura et al., 1997) then $500 \mu \mathrm{L}$ of DNS reagent was added and the mixture was heated for 10 minutes in a boiling water bath to stop the reaction. To stabilize the color, $166 \mu \mathrm{L}$ of sodium potassium tartrate $40 \%$ 
was added, then the mixture was cooled to the ambient temperature and the color intensities were measured by Shimadzu UV-3100 spectrophotometer (Shimadzu Corp., Kyoto, Japan) in cells with $1-\mathrm{cm}$ path length at $575 \mathrm{~nm}$ against the control (control was $400 \mu \mathrm{L}$ of inulin $0.2 \%, 100 \mu \mathrm{L}$ of sodium acetate buffer $\mathrm{pH}$ 5.5, $50 \mathrm{mM}$ ) (Miller, 1959).

Immobilization efficiency was estimated through assaying the protein concentration and/or inulinase activity in the supernatants after 5 minutes of centrifugation at $5000 \mathrm{rpm}$ at room temperature (Heraeus Labofuge $400 \mathrm{R}$, Germany). The Pellets were washed three times with sodium acetate buffer $(\mathrm{pH} 5.5,50 \mathrm{mM})$ to exclude the trapped enzyme molecules. Specific activities were determined based on the milligram of the protein present in the reactionmixture or adsorbed on the support for the free and immobilized enzyme, respectively (Norouzy et al., 2010). The amount of enzyme which liberates $1 \mathrm{mmol}$ of fructose per minute under the standard assay condition (reaction mixture containing $400 \mu \mathrm{L}$ of inulin $0.2 \%$ and $100 \mu \mathrm{L}$ of native or modified inulinases in sodium acetate buffer $\mathrm{pH} 5.5,50 \mathrm{mM}$ and incubation at $45^{\circ} \mathrm{C}$ ) was defined as one unit of inulinase (IU).

\subsection{Alkylation of the nanoporous silica}

Surface area and the porosity of the nanoporous silica were characterized using BrunauerEmmett-Teller (BET) method. About $0.5 \mathrm{~g}$ of the sample was degassed under vacuum for approximately $2.5 \mathrm{~h}$ prior to the adsorption/desorption measurements to remove any moisture or volatiles within the pores of the alkylated nanoporous silica and then exposed to liquid $\mathrm{N}_{2} \mathrm{using}$ a surface analyzer (Quantachrome instruments Nova 2200 e, Odelzhausen, Germany) (Coghetto et al., 2012). For alkylation, $250 \mathrm{~mL}$ toluene was dried by agitating with $10 \mathrm{~g}$ of anhydrous sodium for 24 hours, followed by distillation. Then, OTS dissolved in the dried toluene, was added to the anhydrous nanoporous silica, and left overnight under refluxing to complete the 
alkylation procedure. The alkylation of the support was confirmed using FTIR spectroscopy (Equinox 55, Bruker Company) and IR spectra were recorded using $\mathrm{KBr}$ pellets in the range of $4000-400 \mathrm{~cm}^{-1}$. The result was calculated from a total of 18 scans. Thermo gravimetric analysis (TGA)(TA instrument Q50) was carried out to verify the grafted organic groups on the surface of silica nanoparticles in which, temperature increases by time at $10{ }^{\circ} \mathrm{C} / \mathrm{min}$. At about $100{ }^{\circ} \mathrm{C}$, the initial weight loss occurs which is due to the desorption of physisorbed water, the weight loss at the temperature range of $200-600{ }^{\circ} \mathrm{C}$ is due to the burning of organic moieties of the sample.The breakage that occurs at $350{ }^{\circ} \mathrm{C}$ indicates the functional groups grafted on the surface of silica nanoparticles (Norouzy et al., 2009; Bahrami et al., 20152.5. PLP/ascorbate modification of inulinase

Endo-inulinase $\left(50 \mu \mathrm{L} ; 0.11 \mathrm{mg}^{*} \mathrm{~mL}^{-1}\right)$ was incubated with $450 \mu \mathrm{L}$ of PLP $(1 \mathrm{mM}$ in 50 $\mathrm{mM}$ sodium phosphate buffer, $\mathrm{pH} 7.5$ ) for $30 \mathrm{~min}$ at $25^{\circ} \mathrm{C}$ in the dark. Then the enzyme-PLP complex was reduced by ascorbic acid ( $1 \mathrm{mM}$ in $50 \mathrm{mM}$ phosphate buffer, $\mathrm{pH}$ 7.0). The solution was kept at $4^{\circ} \mathrm{C}$ for 15 min in the dark. Overnight dialysis was performed (MWCO $12 \mathrm{kDa}$ ) against a $50 \mathrm{mM}$ sodium acetate buffer $\left(\mathrm{pH}\right.$ 6.0) at $4^{\circ} \mathrm{C}$ (Torabizadeh et al., 2010). Modified inulinase was compared with the native counterpart using intrinsic fluorescence and thermal stability analysis. The intrinsic fluorescence was recorded in the emission wavelength ranging from 280 to $530 \mathrm{~nm}$ at a concentration of $1 \mathrm{mg}^{*} \mathrm{ml}^{-1}$, by excitation at $280 \mathrm{~nm}$ using Hitachi spectrofluorimeter (Model MPF-4, Tokyo, Japan).The slit width for both excitation and emission was set at $5 \mathrm{~nm}$. For thermal stability analysis of the modification products, the aliquots of the native and modified inulinases were incubated in $50 \mathrm{mM}$ sodium acetate buffer solution, $\mathrm{pH} 5.5$ in the temperature range of $25-65^{\circ} \mathrm{C}$ for $130 \mathrm{~min}$, then their activities were assayed at $37^{\circ} \mathrm{C}$ in the 
same buffer. Assaying $\mathrm{pH}$ was not reproducible for the multiple repeats, since all the assays were done in dioxane containing buffers and adjusting $\mathrm{pH}$ was not reliable.

\section{6. Inulinase immobilization using dioxane-induced unfolding/refolding method}

Extrinsic fluorescence analysis was performed using spectrofluorimeter in a quartz cuvette with $1 \mathrm{~cm}$ path length at $25^{\circ} \mathrm{C}$ using ANS as an indicative of the hydrophobic pockets at the enzyme concentration of $0.1 \mathrm{mg}^{*} \mathrm{ml}^{-1}$ in sodium acetate buffers containing $0-60 \%$ dioxane and the final concentration of ANS at $88.8 \mu \mathrm{M}$. Excitation and emission wavelengths were 350 and 400-600 $\mathrm{nm}$ respectivelyand the maxima of the differential spectra $(\Delta \mathrm{FI})$ were plotted versus dioxane concentration.

Samples of the native and modified inulinases $(200 \mu \mathrm{L})$ at $0.3 \mathrm{mg}^{*} \mathrm{ml}^{-1}$ in sodium acetate buffer (50 mM, pH 5.5) containing 0-60\% (v/v) dioxane were added to $100 \mathrm{mg}$ of hydrated octadecyl nanoporous silica and incubated for 2 hours at $4^{\circ} \mathrm{C}$ in the rotary mixer. They were then centrifuged at $5000 \mathrm{rpm}$ for $5 \mathrm{~min}$ in $4^{\circ} \mathrm{C}$. The supernatants were collected for further analysis and the pellets were washed trice with sodium acetate buffer solution to remove unbound enzymes. Subsequently the immobilized inulinase was stored at $4^{\circ} \mathrm{C}$ until use (Nabati et al., 2011; Norouzy et al., 2010).

\subsection{Characterization of the immobilized inulinases}

Storage stability, reusability and the performance of free and immobilized inulinases in a continuous catalytic operation were studied. Storage stability of the enzymatic processes, principally depends on their ability to retain their bio-catalytic activities over time, thus 6 sets of aliquots (in triplicate) were prepared and stored at $4^{\circ} \mathrm{C}$. The assay was done in sodium acetate buffer ( $\mathrm{pH} 5.5$ ) containing $0.2 \%$ inulin for 30 minutes at $37^{\circ} \mathrm{C}$ with 1 day intervals up to 6 days. The half-life of an enzyme which is the time required to lose 50 percent of the enzyme initial 
activity was calculated according to the equation $t_{1 / 2}=\ln 2 / k_{\text {in }}$ (Torabizadeh et al., 2011). Also, the reusability analysis of the immobilized inulinases (native and modified) was investigated for 10 hydrolysis cycles, while each cycle lasted 8 hours in a continuous operation mode. Immobilized inulinases were stored in $4^{\circ} \mathrm{C}$ during 10 day intervals. To perform continuous operation, solid particles of the support must be retained by the filter designed at the top of the hydrolysis chamber of the bioreactor. For the continuous catalytic operation, sodium acetate buffer, $\mathrm{pH} 5.5$ containing $2 \%$ inulin at $45^{\circ} \mathrm{C}$ (temperature was maintained by circulating water through the jacket) was pumped at a flow rate of $250 \mu \mathrm{L} \cdot \mathrm{min}^{-1}$ through the fluidized bed mini-bioreactor containing $100 \mathrm{mg}$ of inulinase loaded nanoporous silica, then the fractions of the continuous hydrolysis were collected after achieving the steady state up to 8 hours. The presented values are the mean value of five independent continuous operations assessments. The relative activities were expressed as the ratio of the residual activity to the initial activity in percent (Gill et al., 2006; Norouzy et al., 2010; Norouzy et al., 2009; Catana et al., 2007; Arzeni et al., 2012).

\subsection{HPLC analysis of the bioconversion products of the free and immobilized}

\section{inulinases}

Products of the inulin bioconversion by free and immobilized inulinases (native and modified) were characterized using Reversed-Phase HPLC and the detection was performed through refractive index (Knauer $\mathrm{K}-2301$, Germany) at $30^{\circ} \mathrm{C}$, flow rate of $0.5 \mu 1 . \mathrm{min}^{-1}$, with Eurotech columns and $\mathrm{H}_{2} \mathrm{SO}_{4}(0.01 \mathrm{~N})$ as the mobile phase (Rawat et al., 2015; Trytec et al., 2015) 


\section{Results and Discussion}

Table 1 shows the products ofinulinases (native and modified) bioconversion in the free and immobilized forms using RP-HPLC. Although, the catalytic efficiency decreased upon immobilization, inulin hydrolysis improved in modified inulinases: the yield of fructose production increased 1.11 and 1.48 folds for the modified (free and immobilized) inulinases, compared to native (free and immobilized) respectively.

Results of BET for average grain size, pore size, pore volume and surface area were $22.01 \mu \mathrm{m}, 66 \mathrm{~nm}, 0.488 \mathrm{~cm}^{3} \mathrm{~g}^{-1}$ and $33.62 \mathrm{~m}^{2} \mathrm{~g}^{-1}$, respectively. Schematic figure representing the dioxane induced interactions between inulinase and nanoporous silica which results in immobilization of inulinase on the alkyl groups of the support (Fig. 1). Alkylation of the matrix was confirmed by FTIR spectroscopy; at $2880 \mathrm{~cm}^{-1}$ regionC-H stretching vibration of methylene groups are seen that approves the presence of the functional groups. A broad band at around $1100 \mathrm{~cm}^{-1}$ is related to the $\mathrm{Si}-\mathrm{O}-\mathrm{Si}$ asymmetric stretching vibration. The adsorption bandat 3400 $\mathrm{cm}^{-1}$ is due to the stretching vibrations of the silanol groups on the surface of the silica support(Norouzy et al., 2009; Bahrami et al., 2014) (Fig. 2). The observed peak at $1720 \mathrm{~cm}^{-1}$ could represent the capture of $\mathrm{CO}_{2}$ on the sample surface which is mostly seen in functionalized silica particles (Kim et al., 2015)

Specific activities of the inulinases, loaded on the nanoporous silica support were $1.42 \pm 0.21,1.61 \pm 0.24,3.52 \pm 0.15$ and $3.78 \pm 0.28 \mu \mathrm{mol} . \mathrm{min}^{-1} . \mathrm{mg}^{-1}$ for free native, free modified, immobilized native and immobilized modified inulinases, respectively. Improvement in the specific activity following the adsimmobilization has also been reported by Nabati et al., 2011 and Norouzi et al., 2010. 
Preferential chemical modification of the non-catalytic domain of endo-inulinase to enhance the thermostability was done through semi-rational chemical modification of the accessible lysine residues by adding PLP to form Schiff bases, then reducing them by ascorbate (Torabizadeh et al., 2010; Torabizadeh et al., 2011). We have previously reported supporting results on the inulinase modification, including the increase in $\alpha$-helix content and the melting temperature (Tm) using spectropolarimetric (CD) and calorimetric (DSC) methods in details (Torabizadeh et al., 2011; Shapiro et al., 1968). However, to ensure the modification procedure, intrinsic fluorescence after excitation at $280 \mathrm{~nm}$ and also endo-inulinase thermal stability analysis were done, the results of which are presented in Fig. 3, confirming the altered emission and more efficient activity retaining capacity of inulinase after modification. This could be due to the development of the new intra-molecular electrostatic interactions between covalently attached PLP-Lys 381 with $\operatorname{Arg}_{526}$ and Ser $_{376}$ which advances the structural, functional and thermal stability of the PLP-modified endo-inulinase. Applying molecular dynamics stimulation (by using the GROMACS program version 4.0.3). make the simulation of the PLP-modified inulinase, possible which proves the formation of the new contacts between covalently attached PLP-Lys381 with guanidinium group of Arg526 and the hydroxyl group of Ser376 as a result of modification which are considered to be the reason for improved thermostability of the plpmodified enzyme. In addition, the results of intramolecular interactions analysis of inulinase gained by docking approach after PLP-modification at the Lys381 using the LIGPLOT program proves the formation of new hydrogen bonds between the phosphate group of PLP and Arg526 and Ser376 as well(Torabizadeh et al., 2011). A significant improvement in the thermal stability of the enzyme after immobilization has already been reported (Catana et al., 2007; Bajpal \& Margaritis, 1985; Kim et al., 1982; Wenling et al., 1999) which was so remarkable in the 
chemically modified inulinase compared to the native one. Structural analysis of the native and modified inulinases were done at each ratio of dioxane to find the best solvent polarity that forms inulinase intermediate state molecules and exposed substituted alkyl chains. It was found that $40 \%$ and $\sim 50 \%(\mathrm{v} / \mathrm{v})$ of dioxane in sodium acetate buffer for the native and modified inulinasesdeeply affects the emission of ANS which is a reporter of the surface hydrophobicity of the proteins (Hu et al., 2013; Arzeni et al., 2012; Kato \& Nakai, 1980). Differential analysis of ANS fluorescence emission confirmed the surface hydrophobicity increase in native and modified inulinases at $40 \%$ and $\sim 50 \%$ (v/v) of dioxane, respectively (Fig. 4a). The observed minimum intensity in ANS fluorescence emission could be due to the decrease in the protein surface hydrophobicity caused by the strengthening of the hydrogen bonds at $20 \%$ and $35 \%$ dioxane for the native and modified inulinases, respectively. As Fig. 4b shows, maximum activities pertaining to the native and modified inulinases on the exposed octadecyl moieties of the alkylated nano porous silica were observed in 40 and $50 \%$ dioxane (v/v) as well. Thus, it could be concluded that the refolding intermediates express the optimum hydrophobic interaction with exposed alkyl groups of the support at the above mentioned polarities (Nabati et al., 2011). However, at dioxane concentrations beyond what is required to form intermediate state, a protein molecule unfolds, edenatures and deactivates, which explains the observed decrease in the extent of enzyme immobilization at dioxane concentrations higher than 60\% (Risso et al., 2010).

The main preference of the modification and immobilization of endo-inulinase was to improve the storage stability and reusability of the modified and immobilized enzymes compared to the native and free inulinases (Torabizadeh et al., 2010). Immobilization imposes no significant activity loss (based on specific activity analysis) in spite of the mass transfer restrictions. Activity improvement of inulinase after immobilization has been recently stated by 
Kovaleva et al. (2009), Artiukhov et al. (2010) and Karimi et al., (2014) a, b. The hydrolytic activity of free and immobilized inulinases were assayed in three repeats at one day intervals up to 6 days and the corresponding half-lives are presented in inset to Fig. 5. The results showed that the activity loss of the immobilized enzyme was less compared to the free enzyme (both native and modified). Activity loss could be due to enzyme leakage or intrinsic loss of activity. It has been reported that if adsorbtion is the only method applied to attach the enzyme to the support in inulin hydrolysis, inulinase activity would be lost in repeated batches due to leaching most of the protein to the medium (Yewale et al., 2013). Similarly, activity loss of the modified enzyme was far less than the native enzyme which confirms the stabilizing effect of the modification and immobilization of the inulinase. Considering the results presented in the inset to the Fig. 5, immobilized-modified, free modified and immobilized native samples had 7.89, 3.73 and 1.24 fold increase in their half lives in comparison with the free native sample.

Continuous catalytic operations of the inulin hydrolysis was achieved using a simple stirred fluidized bed mini-bioreactor (FBR) as depicted in Fig. 6. After 8 hours of the continuous operation at $45^{\circ} \mathrm{C}$, modified and native inulinases could retain $90.32 \%$ and $80.46 \%$ of their original activities, respectively. Moreover, 40 and $30 \%$ activity retaining was reported for immobilized inulinases (native and modified) respectively, when reusing for 10 day intervals up to 100 days. Inset to Fig. 6 shows a homemade stirred glass fluidized bed bioreactor used for the continuous hydrolysis of inulin. 


\section{Conclusions}

Using inulinase to hydrolyze inulin is an economical and widely applied strategy to produce high fructose syrup in industry, mainly because it is a single-step reaction. In this research, the efficiency of the dioxane induced unfolding/refolding absorptive immobilization method for the immobilization of the modified/thermo-stabilized inulinase along with the native enzyme was verified. Our results support the performance of this modification/immobilization strategy for the applied approaches. 


\section{Acknowledgements}

We state our deep appreciation to Dr. Alireza Badiei and Dr. Zohreh Bahrami for their cooperation in the porosimetry and alkylating of porous silica. This work was funded by a grant

from the Research Council of the University of Tehran. Also the Institute of BiophysicsBiochemistry, University of Tehran is gratefully acknowledged. The center of excellence for application of modern technologies for producing functional foods and drinks is highly acknowledged. 


\section{References}

Artiukhov, V. G., Kovaleva, T. A., Kholiavka, M. G., Bitiutskaia, L. A., Grechkina, M. V. (2010). Thermal inactivation of free and immobilized inulinase, prikl biokhim. Microbiol. 46, 422-427.

Arzeni, C., Perez, O. E., Pilosof, A. M. R. (2012). Functionality of egg white proteins as affected by high intensity ultrasound, Food Hydrocolloid. 29, 308-316.

Bajpal, P., and Margaritis, A. (1985). Application of Immobilized Cells of $K$. marxianus for continuous Hydrolysis to Fructose of Fructans in Jerusalem Artichoke, Enzyme Microb. Tech. 7, 373-376.

Barranco-Florido, E., Garcia-Garibay, M., Gomez-Ruiz, L., Azaola, A. (2001). Immobilization system of Klyveromyces marxianus cells in barium alginate for inulin hydrolysis, Process Biochem. 37, 513-519.

Barthomeuf, C., Regerat, F., Pourrat, H. (1991). Production of inulinase by a new mold of Penicillium rugulosum, J. Ferment. Bioeng. 72, 491-494.

Bradford, M. M. (1976). A rapid and sensitive method for the quantitation of microgram quantities of protein utilizing the principle of protein-dye binding, Anal. Biochem. 72, 248-254.

Catana, R., Eloy, M., Rocha, J. R., Ferreira, B. S., Cabral, J. M. S., Fernandes, P. (2007). Stability evaluation of an immobilized enzyme system for inulin hydrolysis, Food Chem. 101, 260-266.

Coghetto, C. C., Scherer, R. P., Silva, M. F., Golunski, S., Pergher, S. B. C., Oliveira, D., Oliveira, J. V., Treichel, H. (2012). Natural montmorillonite as support for 
the immobilization of inulinase from Kluyveromyces marxianus NRRL Y-7571, Biocatal. Agric. Biotechnol. 284-289.

Cruz, V. D., Belote, J. G., Belline, M. Z., Cruz, R. (1998). Production and action pattern of inulinase from Aspergillus niger-245, hydrolysis of inulin from several sources, Annu. Rev. Microbiol. 29, 301-306.

Ettalibi, M., Baratti, J. C. (2001). Sucrose hydrolysis by thermostable immobilized inulinases from Aspergillus ficuum, Enzyme Microb. Technol. 28, 596-601.

Gill, P. K., Manhas, R. K., Singh, P. (2006). Comparative analysis of thermostability of extracellular inulinase activity from Aspergillus fumigatus with commercially available (Novozyme) inulinase, Bioresource Technol. 97, 894-902.

Hu, H., Wu, J., Li-Chan, E. C. Y ., Zhu, L., Zhang, F., Xu, X., Fan, G., Wang, L., Huang, X., Pan, S. (2013). Effects of ultrasound on structural and physical properties of soy protein isolate (SPI) dispersions, Food Hydrocolloid. 30, 647655.

Karimi M., Habibi-Rezaei, M., Safari, M. Chaudhury I., Jianjun C., Kokini, J. (2014) (a) Immobilization of endo-inulinase on non-porous aminofunctionalized silica nanoparticles; Journal of Molecular Catalysis B enzymatic, 104, (48-55).

Karimi M., Habibi-Rezaei, M., Safari, M., Sayyah, M., Sadeghi, R., Kokini, J. (2014) (b) Immobilization of endo-inulinase on Poly-D-Lysine coated $\mathrm{CaCO}_{3}$ microparticles; Food research international, 66, 485-492. 
Kato, A. and Nakai, S. (1980). Hydrophobicity determined by a fluorescence probe method and its correlation with surface properties of proteins, Biochim. Biophys. Acta. 624, 13- 20.

Kim H., Yang H. C., Chung D.Y., Yang I. H., Choi Y. J., Moon J. (2015) Functionalized Mesoporous Silica Membranes for $\mathrm{CO}_{2}$ Separation Applications, J.Chem., 2015, 1-9 .Kim, K. Y., Rhee, S., Kim, S. I. (2005). Role of the Nterminal domain of endo inulinase from Arthrobacter sp. S37 in regulation of enzyme catalysis, J. Biochem. 138, 27-33.

Kim, W. Y., Byun, S. M. and Uhm, T. B. (1982). Hydrolysis of inulin from Jerusalem Artichoke by inulinase immobilized on aminoethylcellulose, Enzyme Microb. Tech. 4, 239-244.

Knubovets, T., Osterhout, J. J., Klibanov, A. M. (1999). Structure of lysozyme dissolved in neat organic solvents as assessed by NMR and CD spectroscopies, Biotechnol. Bioeng. 63, 242-248.

Kovaleva, T. A., Holyavka, M. G., and Bogdanova, S. S. (2009). Inulinase immobilization on macroporous anion-exchange resins by different methods, B Exp. Biol. Med. 148, 39-41.

Miller, G. L. (1959). Use of dinitrosalicylic acid reagent for determination of reducing sugar, Anal. Chem. 31, 426-428.

Nabati, F., Habibi-Rezaei, M., Amanlou, M., Moosavi-Movahedi, A. A. (2011). Dioxane enhanced immobilization of urease on alkyl modified nano-porous silica using reversible denaturation approach, J. Mol. Catal. B Enzym. 70, 17-22. 
Nagem, R. A. P., Rojas, A. L., Golubev, A. M., Korneeva, O. S., Eneyskaya, E. V., Kulminskaya, A. A., Neustroev, K. N., Polikarpov, I. (2004). Crystal structure of exo-inulinase from Aspergillus awamori in spacegroup P21, J. Mol. Biol. 344, 471-480.

Nakamura, T., Ogata, Y., Shitara, A., Nakamura, A., Ohta, K. (1995). Continuous production of fructose syrup from inulin by immobilized inulinase from Aspergillus niger mutant 817, J. Ferment. Bioeng. 80, 164-169.

Nakamura, T., Shitara, A., Matsuda, S., Matsuo, T., Suiko, M., Ohta, K. (1997). Production, purification and properties of an endoinulinase of Penicillum sp. TN88 that liberates inulotriose, J. Ferment. Bioeng. 84, 313-318.

Norouzy, A., Qujeq, D., Habibi-Rezaei, M. (2009). The inhibitory effect of dissolved carbaryl in dioxane on physically adsorbed acetylcholinesterase, React. Kinet. Catal. L. 98, 391-401.

Norouzy, A., Habibi-Rezaei, M., Qujeq, D., Vatani, M. and Badiei, A. (2010). Adsorptive Immobilization of Acetylcholine Esterase on Octadecyl Substituted. Porous Silica, Optical Bio-analysis of Carbaryl, Korean Chem. Soc.. 31, 157161.

Pandey, A., Soccol, C. R., Selvakumar, P., Soccol, V. T., Krieger, N., Fontana, J. D. (1999). Recent developments in microbial inulinases. Its production, properties, and industrial applications, Appl. Biochem. Biotech. 81, 35-52.

Rawat H. K., Ganaie M. A., Kango N. (2015) Production of inulinase, fructosyltransferase and sucrose from fungi on low-value inulin-rich substrates 
and their use in generation of fructose and fructo-oligosaccharides, Antonie van Leeuwenhoek, 107, 799-811.

Risso, F. V. A., Mazutti, M. A., Costa, F., Treichel, H., Costa, F., Maugeri, F., Rodrigues, M. I. (2010). Comparative studies of the stability of free and immobilized inulinase from Kluyveromyces marxianus NRRL Y-7571 in aqueous-organic solutions, Food Technol. Biotech. 48, 143-150.

Rocha, J. R., Catana, R., Ferreira, B. S., Cabral, J. M. S., Fernandes, P. (2006). Design and characterization of an enzyme system for inulin hydrolysis, Food Chem. 95, $77-82$.

Ronkarta, S. N., Bleckera, C. S., Fourmanoira, H., Fougniesc, C., Deroannea, C., Herckc, J. V., Paquotb M. (2007). Isolation and identification of inulooligosaccharides resulting from inulin hydrolysis, Anal. Chem. 604, 81-88.

Sassolas, A., Blum, L. J., Leca-Bouvier, B. D. 2012. Immobilization strategies to develop enzymatic biosensors, Biotechnol. Adv. 30, 489-511.

Shapiro, S., Enser, M., Pugh, E., Horecker, B. L. (1968). The effect of pyridoxal phosphate on rabbit muscle aldolase, Arch. Biochem. Biophys. 128, 554-562.

Torabizadeh, H., Habibi-Rezaei, M., Safari, M., Moosavi-Movahedi, A. A., Sharifizadeh, A., Azizian, H., and Amanlou, M. (2011). Endo-inulinase Stabilization by Pyridoxal Phosphate Modification, A Kinetics, Thermodynamics and Simulation Approach, Appl. Biochem. Biotech. 165, 1661-1673. 
Torabizadeh, H., Habibi-Rezaei, M., Safari, M., Moosavi-Movahedi, A. A. (2010). Semi-rational chemical modification of endoinulinase by pyridoxal 5-phosphate and ascorbic acid, J. Mol. Catal. B Enzym.62, 257-264.

Tourné-Péteilh C., Lerner D.A., Charnay C., Nicole L., Begu S., Devoisselle J.M, (2003) The potential of ordered mesoporous silica for the storage of the drugs; the example of a pentapeptide encapsulated in a MSU-Tween 80, Chem. Phys. Chem., 4 281-286.

Trytek M., Fiedurek J., Podkoscielna B., Gawdzik B., Skowronek M (2015) An efficient method for the immobilization of inulinase using new types of polymers containing epoxy groups. J Ind Microbiol Biotechnol 42:985-996.

Uzunova, K., Vassileva, A., Ivanova, V., Spasova, D., Tonkova, A. (2002). Thermostable exo-inulinase production by semicontinuous cultivation of membrane-immobilized Bacillus sp. 11 cells. Process Biochem, Process Biochem. 37, 863-868.

Vasileva, N., Godjevargova, T. (2005). Study of the effect of some organic solvents on the activity and stability of glucose oxidase, Mater. Sci. Eng. 25, 17-21.

Wenling, W., Huiying, W. W. L. and Shiyuan, W. (1999). Continuous preparation of fructose syrups from Jerusalem artichoke tuber using immobilized intracellular inulinase from Kluyveromyces sp. Y-85, Process Biochem. 34, 643-646.

Yewale T., Singhal R. S., Vaidya A.A. (2013). Immobilization of inulinase from Aspergillus niger NCIM 945 on chitosan and its application in continuous inulin hydrolysis, Biocatal. Agric. Biotechnol., 2, 96-101. 
Bahrami Z., Badiei A., Atyabi F., Darabi H. R., Mehravi B. (2015) Piperazine and its carboxylic acid derivatives-functionalized mesoporous silica as nanocarriers for gemcitabine: Adsorption and release study, Mat. Sci. Eng. C, 49, 66-74.

Bahrami Z., Badieia A., Atyabic F. (2014) Surface functionalization of SBA-15 nanorods foranticancer drug delivery,chem. eng. Res. Des., 9 2, 1296-1303. 
Table 1. Results of HPLC for the products of inulinases (native and modified) bioconversion.

\begin{tabular}{lccccc}
\hline & Fructose & Glucose & Sucrose & Inulin & Fructose/Inulin \\
\hline Native & 48.04 & 37.80 & 1.68 & 6.19 & 7.7 \\
Modified & 53.30 & 12.40 & - & 4.19 & 12.7 \\
\hline
\end{tabular}

\section{Figure captions}

Fig. 1. Schematic figure of inulinase immobilization on the alkyl groups of the nano porous silica support.

Fig. 2. Infrared spectra of the nano porous silica before (dashed line) and after substitution of octadecyl moieties (continuous line). IR spectra were recorded using $\mathrm{KBr}$ pellets and calculated from a total of 18 scans. For details please see materials and methods section.

Fig. 3. Fluorescence emission spectra of the native and modified inulinases after excitation at $280 \mathrm{~nm}$. Inset to Fig. represents the remaining activities of the native (dashed line) and modified inulinases in $50 \mathrm{mM}$ sodium acetate buffer solution, $\mathrm{pH} 5.5$ after $130 \mathrm{~min}$ incubation at each temperature, then assaying their activities by incubating with $0.2 \%$ inulin in the same buffer for 30 minutes at $37^{\circ} \mathrm{C}$.

Fig. 4. ANS fluorescence emission intensities of the native and modified inulinases as function of dioxane concentrations at the final concentration of $88.8 \mu \mathrm{M}$ ANS (a). Data correction was performed by subtracting the ANS emission in the absence of the inulinase from the one in the presence of inulinase in sodium acetate buffers containing 0 to $60 \%$ dioxane. The ANS excitation wavelength was $350 \mathrm{~nm}$ and the emission spectra were between 400 and $600 \mathrm{~nm}$. 
Immobilization of the native and modified inulinases on octadecyl substituted nano porous silica based on the immobilized activities (b). They were also presented in the buffers containing 0 to $60 \%$ dioxane.

Fig. 5. Storage stability of the free and immobilized inulinases (native and modified). Free and immobilized aliquots were assayed after storing at $4{ }^{\circ} \mathrm{C}$ up to 6 days (a). Rreusability of the immobilized inulinases (native and modified) for 10 hydrolysis cycles. Immobilized inulinases were stored in $4^{\circ} \mathrm{C}$ between the intervals (b).

Fig. 6. Results of the continuous operations. $100 \mathrm{mg}$ of inulinase loaded octadecyl substituted nano porous silica was injected into the bioreactor. The reaction mixture (sodium acetate buffer $50 \mathrm{mM}$, pH 5.5 containing $2 \%$ inulin) was pumped through the reactor at a constant flow rate of $250 \mu \mathrm{L} \cdot \mathrm{min}^{-1}$ and the samples were collected and used to determine the liberated fructose content by DNS method. Inset to figure represents the homemade stirred glass fluidized bed bioreactor used for the continuous hydrolysis of inulin at $45^{\circ} \mathrm{C}$. 


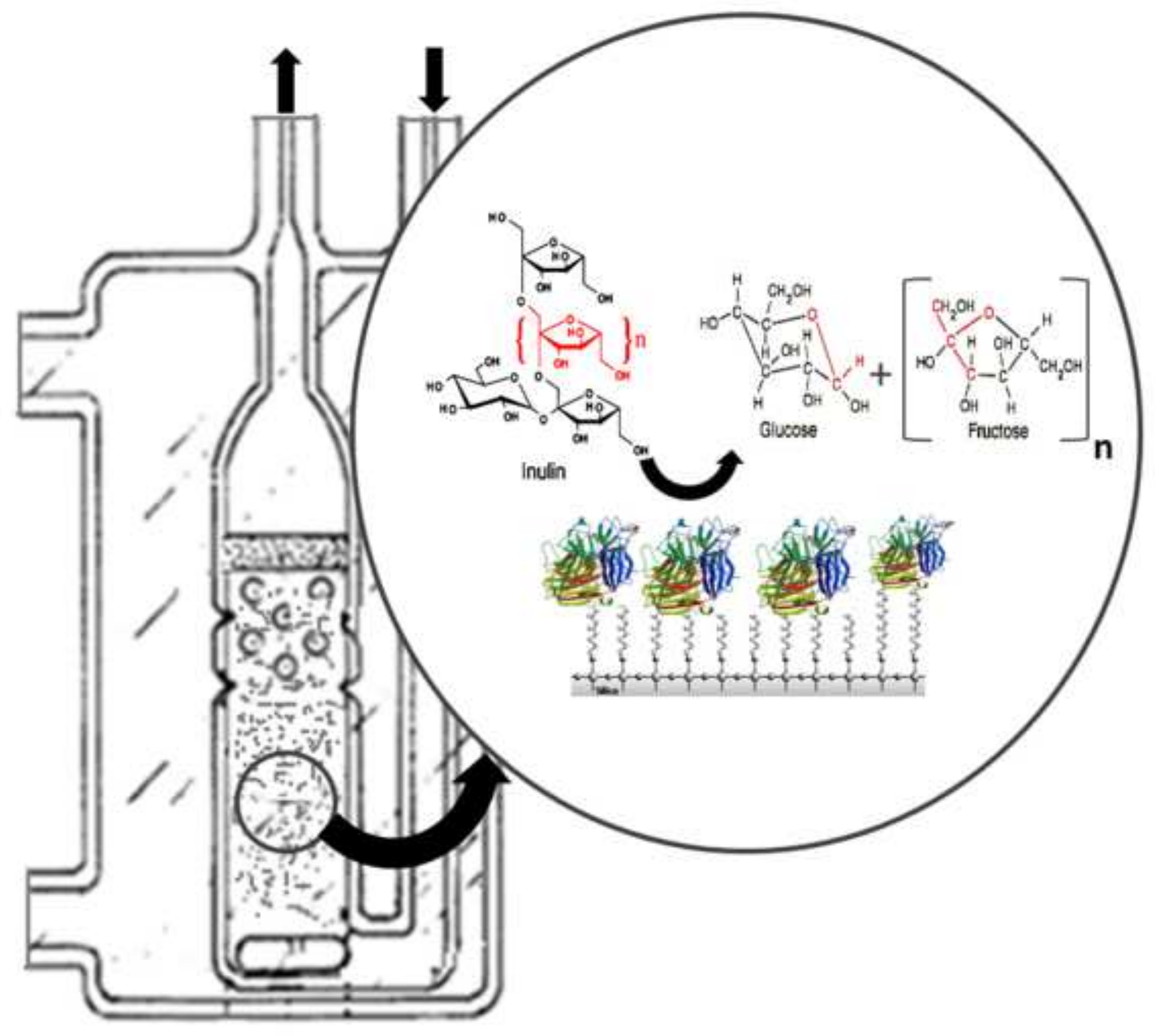




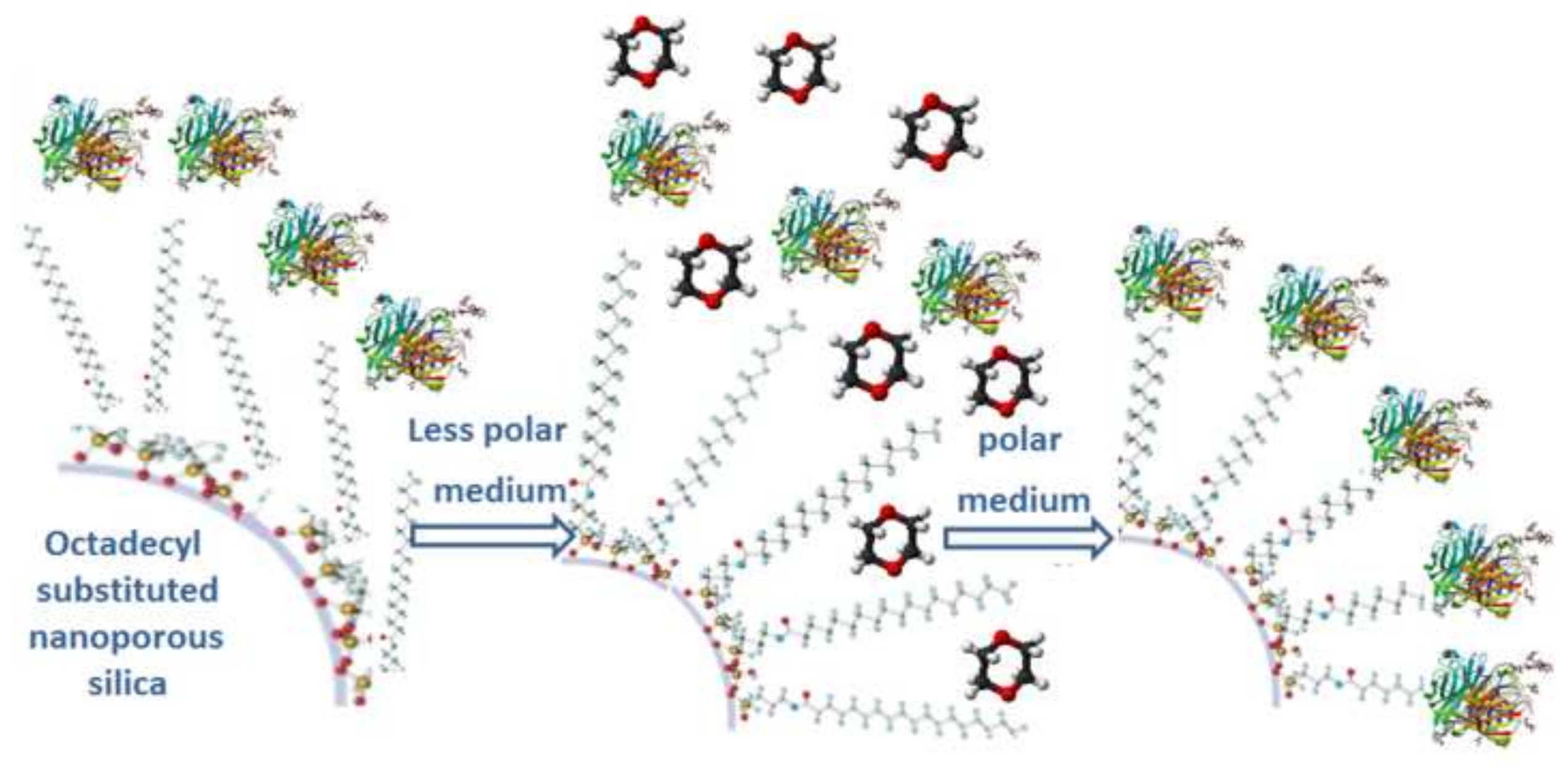




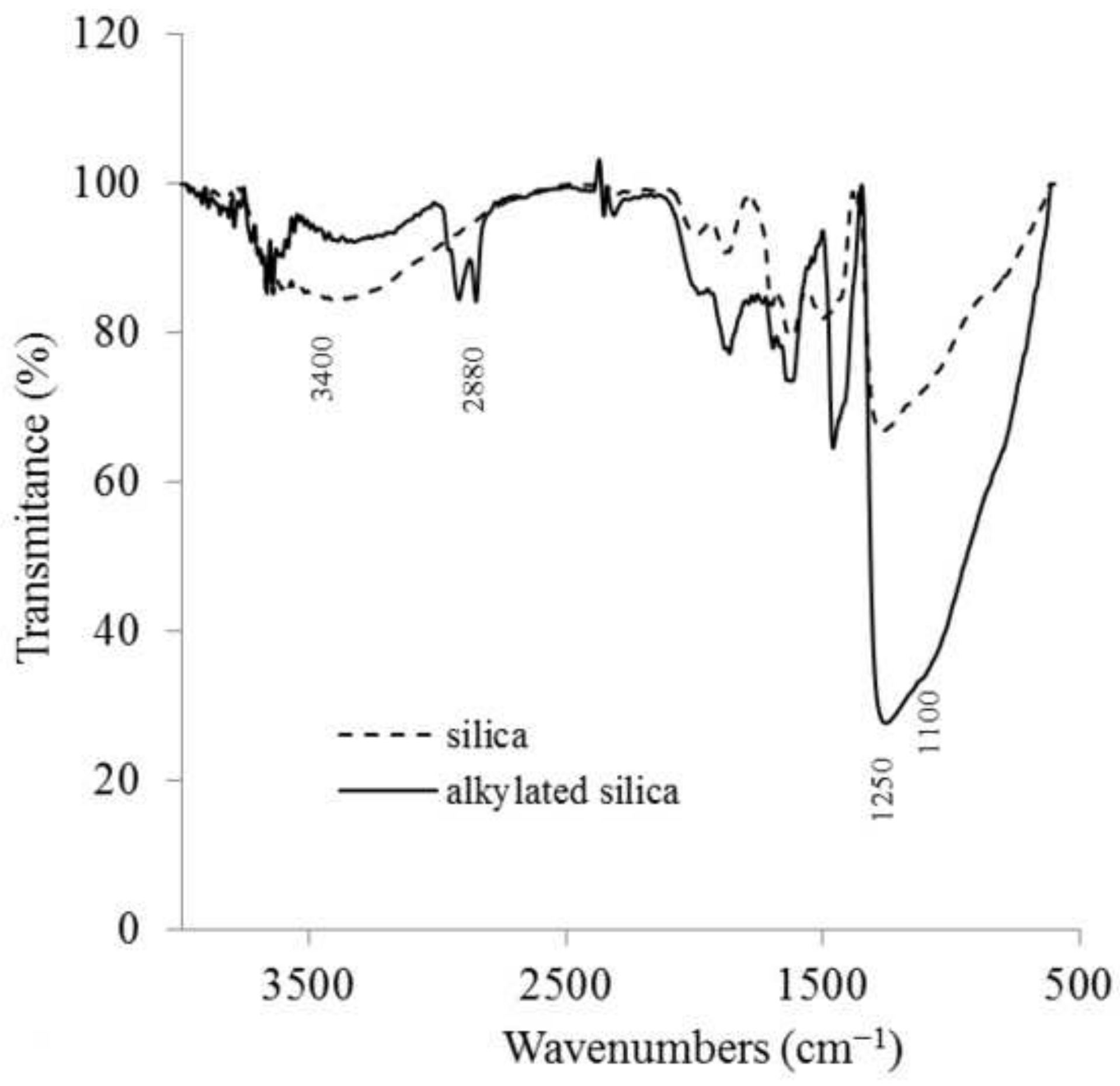




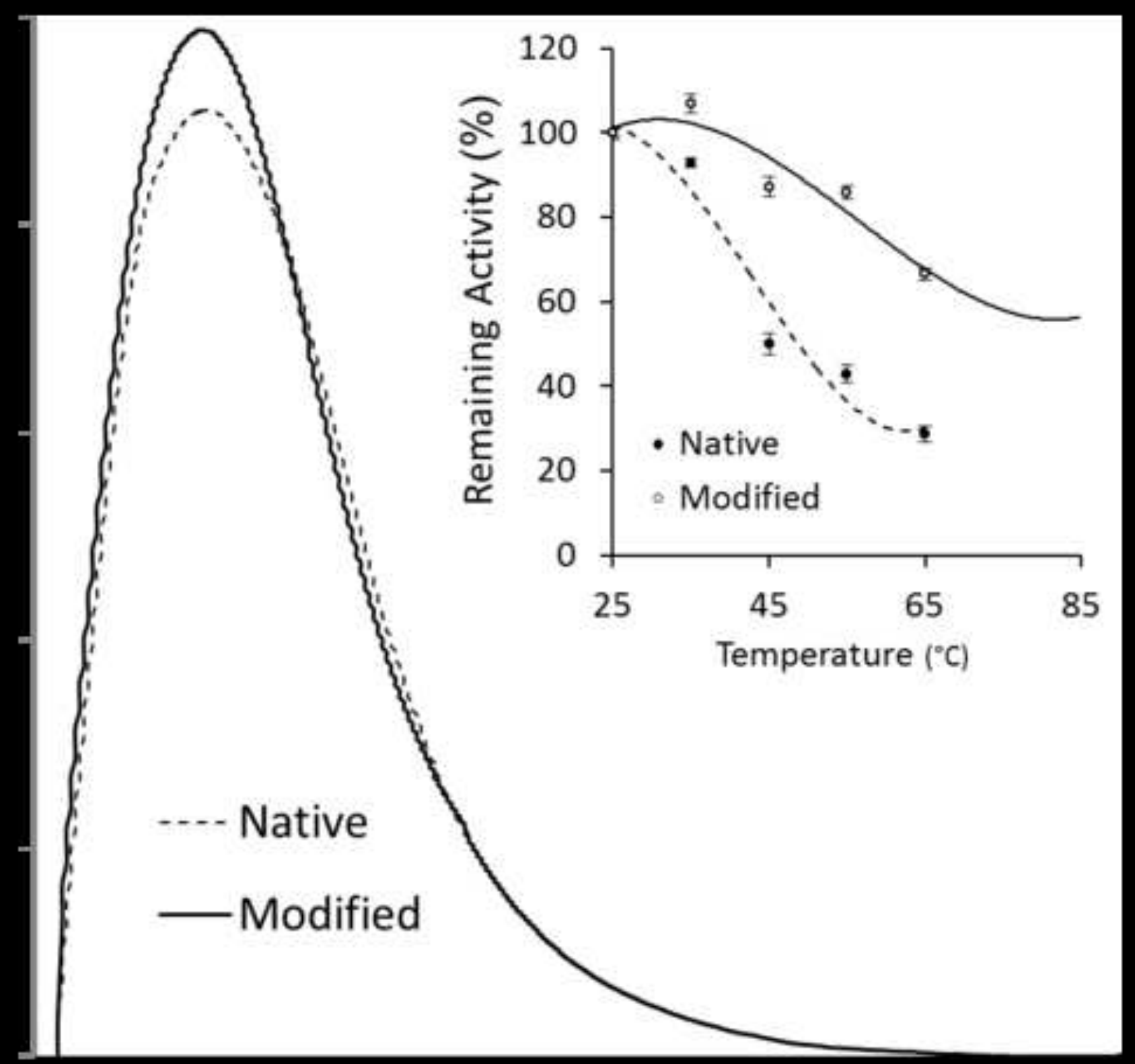



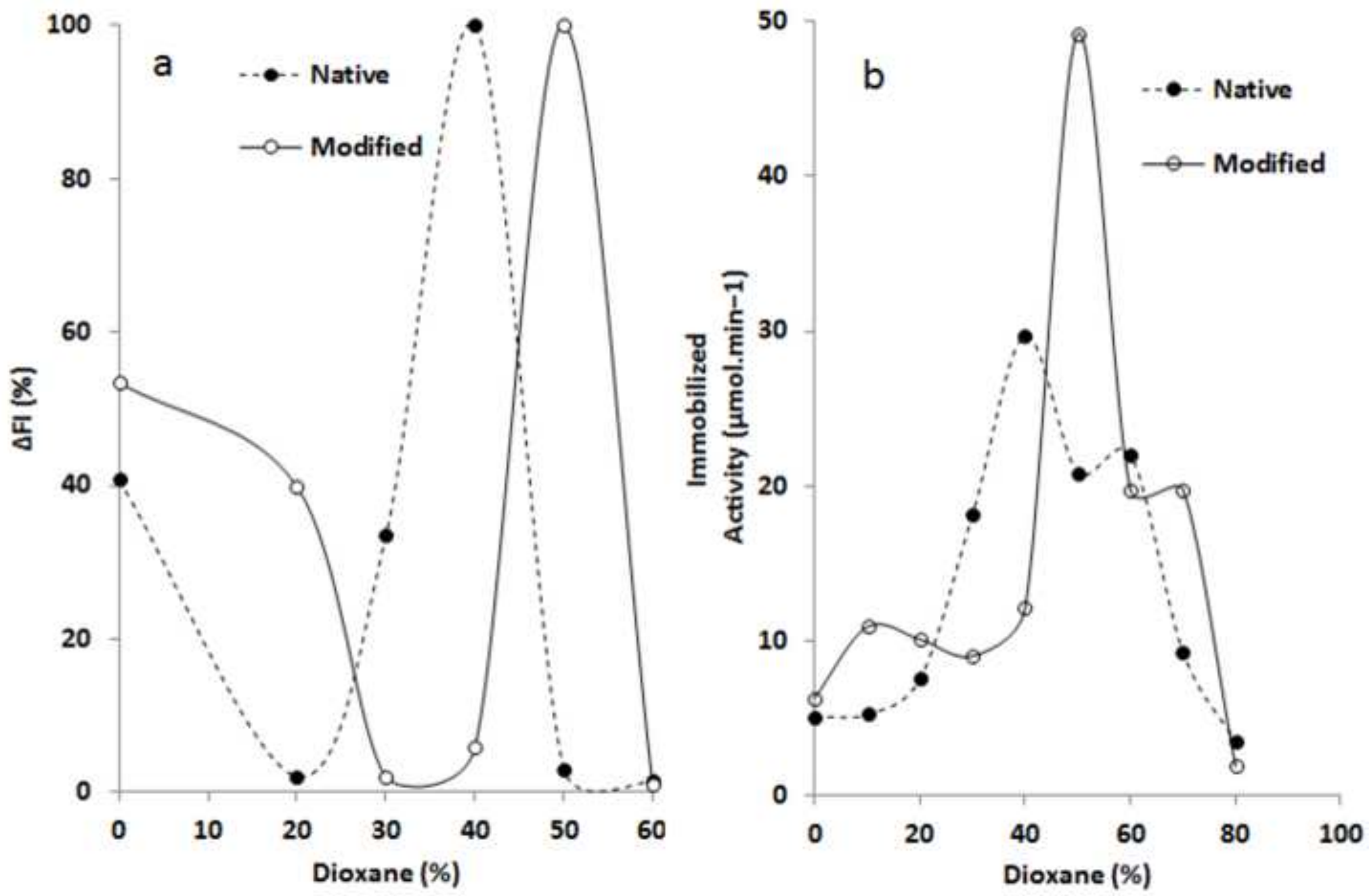


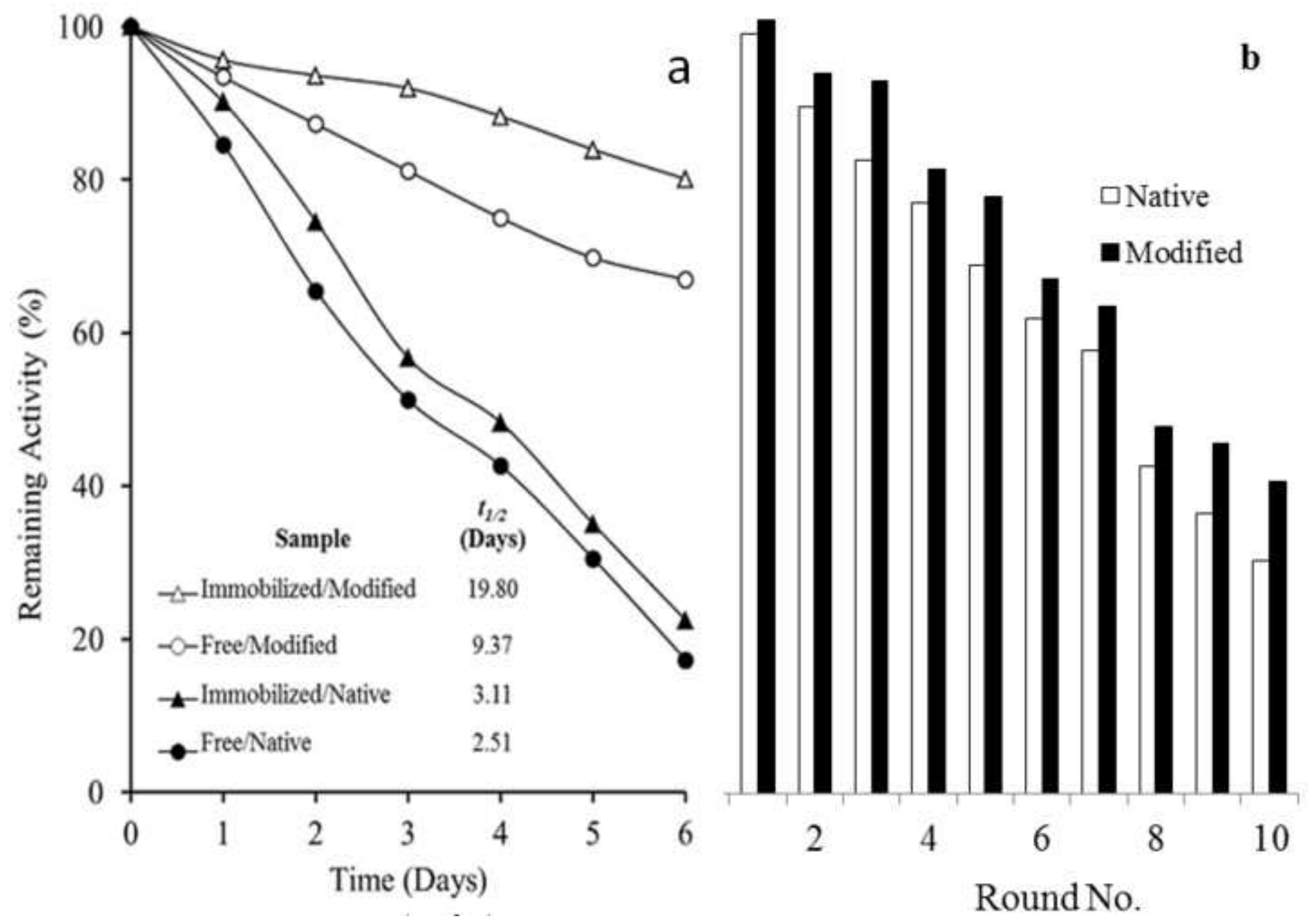




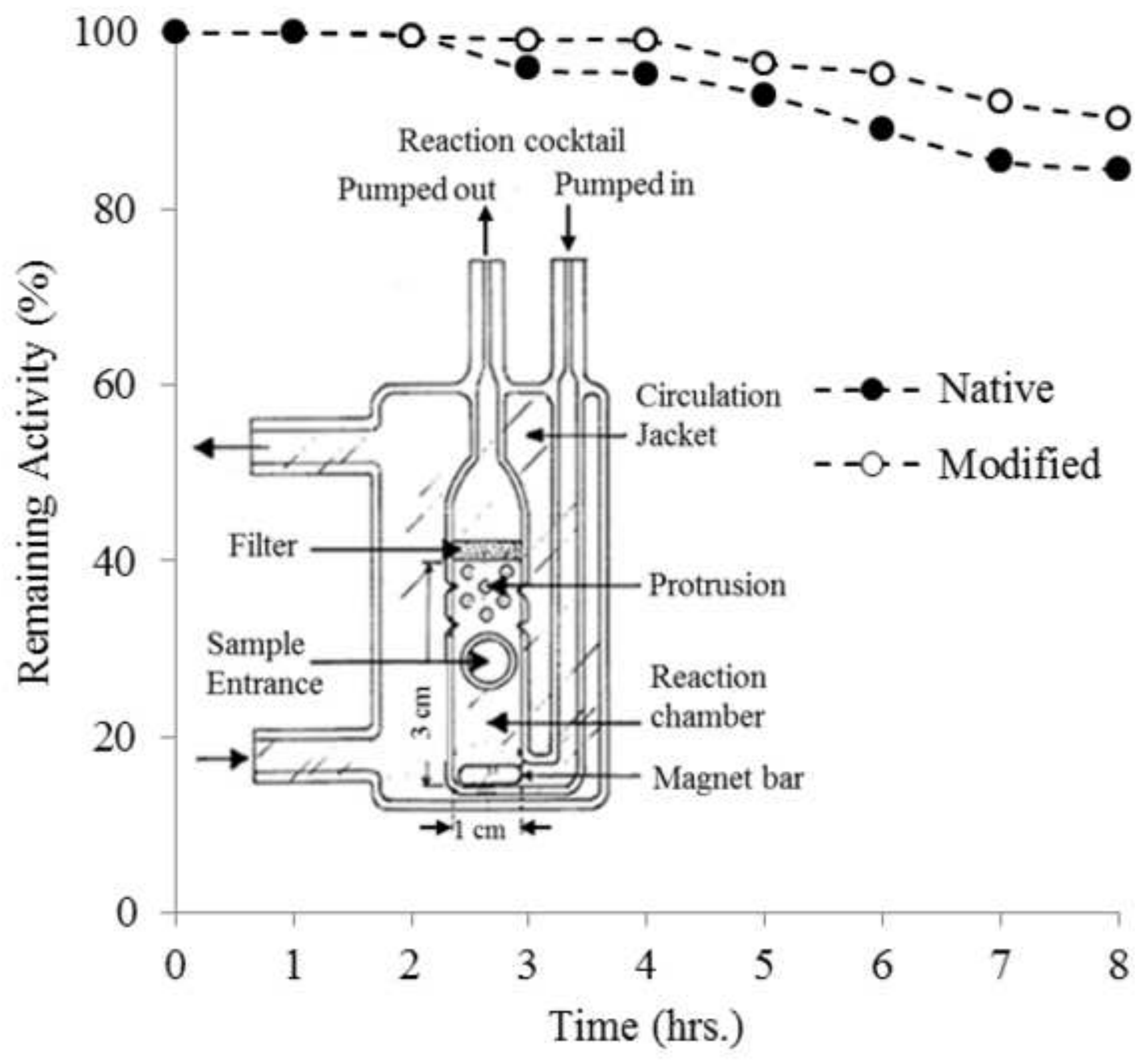

